\title{
Ring-Opening Polymerisation of rac-Lactide Using a Calix[4]arene-Based Titanium (IV) Complex
}

\author{
Marco Frediani, ${ }^{1}$ David Sémeril, ${ }^{2}$ Dominique Matt, ${ }^{2}$ Luca Rosi, ${ }^{1}$ Piero Frediani, ${ }^{1}$ \\ Fabio Rizzolo,, ${ }^{1,3}$ and Anna Maria Papini ${ }^{1,3}$ \\ ${ }^{1}$ Department of Chemistry "Ugo Schiff”, University of Florence, Via della Lastruccia 13, 50019 Sesto Fiorentino, Italy \\ ${ }^{2}$ Laboratoire de Chimie Inorganique Moléculaire et Catalyse, UMR 7177 CNRS, Université de Strasbourg, 1 rue Blaise Pascal, \\ 67008 Strasbourg Cedex, France \\ ${ }^{3}$ Laboratory of Peptide \& Protein Chemistry \& Biology, Scientific and Technological Park, University of Florence, \\ 50019 Sesto Fiorentino, Italy
}

Correspondence should be addressed to Marco Frediani, marco.frediani@unifi.it

Received 21 December 2009; Accepted 10 February 2010

Academic Editor: Jose Ramon Leiza

Copyright (C) 2010 Marco Frediani et al. This is an open access article distributed under the Creative Commons Attribution License, which permits unrestricted use, distribution, and reproduction in any medium, provided the original work is properly cited.

\begin{abstract}
cone-25,27-Dipropyloxy-26,28-dioxo-calix[4] arene titanium (IV) dichloride (1) has been assessed in the ring-opening polymerisation of rac-lactide ( $L, D$-LA). The polymers formed (PLDA) turned out to display an isotactic stereoblock microstructure (determined by NMR) despite the fact that the catalyst has $C_{2 \mathrm{v}}$ symmetry. Two techniques were applied for initiating the polymerisation reaction, microwave irradiation, and conventional thermal treatment. The polymers obtained were all characterised by NMR, IR, HPLC-SEC, DSC, and MALDI-TOF analysis. The use of microwave irradiation, applied for the first time to calixarene-based catalysts in the presence of the rac-lactide monomer, increased the polymerisation rate compared with that obtained by the other method. On the other hand, standard thermal treatment enabled a slightly better control than microwave irradiation over the molecular weight and molecular weight distribution of the polylactides formed.
\end{abstract}

\section{Introduction}

Poly(lactic acids) (PLAs) are biocompatible and biodegradable materials with potential applications in medicine and agriculture, as well as packaging materials. The most efficient method for the synthesis of PLAs is the ring opening polymerisation (ROP) of lactide (LA), which possesses two chiral centers [1-4]. The stereochemistry of the polymer formed determines its physical and mechanical properties, as well as its rate of degradation, and it is therefore important to ensure stereocontrol of the polymerisation process [5-8].

Among the most used catalysts for the ring opening polymerisation of LA, notably in industry, are organotin compounds, for example, $\mathrm{Sn}(\mathrm{Oct})_{2}$ [9-12]. A major drawback to the use of these tin derivatives is their high toxicity. In this context, the development of new, performing catalysts based on non toxic metals (e.g., group IV transition metals) remains an important challenge [13-20].

Calix[4]arenes are macrocyclic molecules made of four phenol units linked via methylene bridges connected to the ortho positions of the phenol rings. The presence of four oxygen atoms at the lower rim of these conical molecules provides a valuable platform for the synthesis of poly(phenoxy) metal complexes. Recently, we have reported on a calix[4]arene titanium complex that was found to be active in the ROP of $L$-LA [21]. Here, the calixarene moiety behaves as a small oxo surface protecting one face of the complex, thereby confering high thermal stability to it [2225].

In the present work, we describe the use of cone25,27-dipropyloxy-26,28-dioxo-calix[4] arene titanium (IV) dichloride (1) in the ROP of rac-lactide ( $L, D$-LA) under thermal activation. The polymerisation was also carried out 


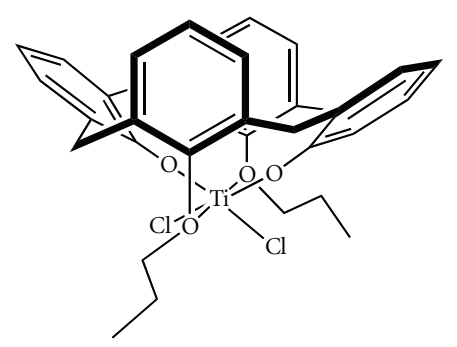

(1)

Scheme 1: Structure of cone-25,27-dipropyloxy-26,28-dioxo-calix[4] arene titanium (IV) dichloride.

under microwave irradiation, which is an emerging field of research in polymer chemistry [26-35] (see Scheme 1).

\section{Experimental}

2.1. General. The manipulations of air- and/or watersensitive compounds were performed under a nitrogen atmosphere using either standard Schlenk techniques or a MBraun glove box. rac-Lactide ( $L, D$-LA) was obtained from Aldrich $(>98 \%)$ and purified. The cone-25,27-dipropyloxy26,28-dioxo-calix[4] arene titanium (IV) dichloride (1) was prepared using a method reported in the literature [36].

2.2. Polymerisation Experiments. $L, D$-LA polymerisation was carried out by charging the desired amount of monomer and the appropriate amount of complex (1) into a vial. The vial was either immersed into an oil bath at $130^{\circ} \mathrm{C}$ or introduced automatically into a microwave oven (Discover SClass System, CEM). A maximal power of $200 \mathrm{~W}$ was applied for the specified time while the temperature was monitored by an IR sensor positioned below the vial.

2.3. Polymer Characterisation. ${ }^{1} \mathrm{H}$ NMR and ${ }^{13} \mathrm{C}$ NMR spectra were recorded on a Varian Mercury 400 apparatus using $\mathrm{CDCl}_{3}$ as the solvent (solution $0.2 \mathrm{w} / \mathrm{w}$ ). Melting temperatures $\left(T_{m}\right)$ of the polymers were determined by differential scanning calorimetry (DSC) with a Mettler-Toledo DSC 821e instrument equipped with an intracooler. The temperature scale was calibrated with an indium reference sample (melting transition of indium $156.1^{\circ} \mathrm{C}$ ). Aluminum pans were filled with $0.010 \mathrm{~g}$ of the polymer sample. The thermal history of the polymers was eliminated by heating the specimen at a rate of $20^{\circ} \mathrm{C} \cdot \mathrm{min}^{-1}$ to $200^{\circ} \mathrm{C}$ and by keeping the sample at this temperature for one minute, then by cooling it at $20^{\circ} \mathrm{C} \cdot \mathrm{min}^{-1}$ to $0^{\circ} \mathrm{C}$. The second and third scans were then recorded from $0^{\circ} \mathrm{C}$ to $200^{\circ} \mathrm{C}$. The weight average molecular weight $\left(M_{w}\right)$ and molecular weight distribution $\left(M_{w} / M_{n}\right)$ of the polymers were evaluated by size exclusion chromatography (HPLC-SEC) using a Perkin-Elmer type Series 2000 apparatus equipped with a Rheodyne 7010 injector (injection loop $200 \mu \mathrm{L}$, refraction index detector type LC-30 with two PL GEL columns (length: $30 \mathrm{~cm}$; diameter: $5 \mu \mathrm{m}$; Polymer Labs)). The analyses were performed at $30^{\circ} \mathrm{C}$ using chloroform as solvent, with a flow rate of $1.0 \mathrm{~mL} \cdot \mathrm{min}^{-1}$ using polymethylmetacrylate (PMMA) standard to calibrate the system [37]. The samples were prepared by dissolving $0.005-0.006 \mathrm{~g}$ of polymer in $2 \mathrm{~mL}$ of chloroform (corresponding to ca. $3 \mathrm{~g} \cdot \mathrm{L}^{-1}$ ). The WAXD analyses were done using a D8 Advance (Bruker) with a Solx solid state detector, using a Bragg-Brentano Geometry. All the samples were preventively heated at $120-130^{\circ}$ for three days before analysis. The samples were exposed to a $\mathrm{Cu} \mathrm{K} \alpha$ $\mathrm{X}$-ray source with a wave length $(\lambda)$ of $1.541 \AA$. The angle of incidence was varied from $4^{\circ}$ to $50^{\circ}$ by steps of $0.02 \theta$ for a period of 1.5 seconds. The periodical distances $(d)$ of the main peaks were calculated according to Bragg's equation $(\lambda=2 d \sin \theta)$. MALDI-TOF analyses were carried out on a Ultraflex MALDI TOF/TOF from Bruker, with the following instrumental settings. In linear mode IS1 was set to $25 \mathrm{kV}$, IS 2 to $23.70 \mathrm{kV}$, with a delay time of 80 nano seconds. In reflectron mode IS1 was set to $25 \mathrm{kV}$, IS2 to 21.50 , with a delay time of 20 nano seconds.

\section{Results and Discussion}

As reported recently, the polymerisation of $L$-lactide with 1 under microwave conditions leads to isotactic PLLA (see Scheme 2).

In the present work the catalytic runs were carried out under solvent-free conditions, using either conventional heating or microwave irradiation. All analytical investigations (HPLC-SEC [36], DSC [37], NMR [38-41], MALDITOF $[42,43]$, and WAXD [44]) were consistent with the formation of PLLA polymers. The MALDI-TOF spectra unambiguously revealed that transesterification reactions had occurred during polymerisation.

We first investigated the influence of the monomer/ catalyst ratio $([L, D-\mathrm{LA}] /[\mathrm{Ti}])$ (Table 1$)$. Applying a $[L, D$ $\mathrm{LA}] /[\mathrm{Ti}]$ ratio of 200 led to a conversion of $96 \%$, which corresponds to an activity of $9.2 \mathrm{~kg}(\mathrm{PLDA}) \cdot \mathrm{mol}^{-1}(\mathrm{Ti}) \cdot \mathrm{h}^{-1}$ (Table 1 , entry 1$)$. Increasing the $[L, D$-LA $] /[$ Ti $]$ ratio to 1994 increased the catalyst activity, the latter reaching a value of $65.3 \mathrm{~kg}(\mathrm{PLDA}) \cdot \mathrm{mol}^{-1}(\mathrm{Ti}) \cdot \mathrm{h}^{-1}$ (Table 1 , entries 1 4). Within the $200-1500$ range of $[L, D-\mathrm{LA}] /[\mathrm{Ti}]$, a roughly linear dependence of the activity on the $[L, D-\mathrm{LA}] /[\mathrm{Ti}]$ molar ratio was observed (Figure 1). It is noteworthy that the activity of the catalyst was slightly higher in the case of $L, D$ LA than when using L-LA [28]. 


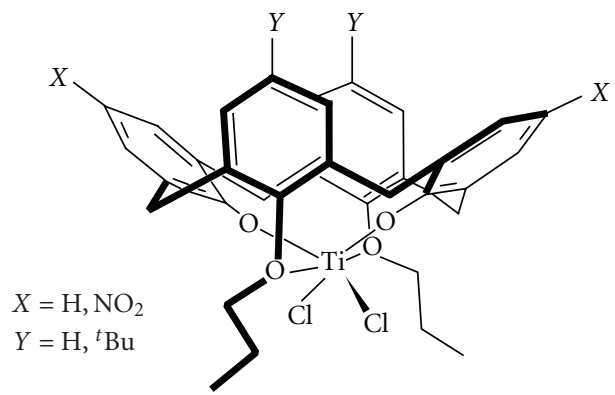<smiles>C[C@@H]1OC(=O)[C@H](C)OC1=O</smiles>

$L$-lactide

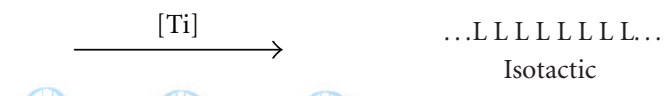

Microwave

Scheme 2: Ring opening polymerisation of $L$-lactide under microwave irradiations.

TABLE 1: Thermally induced polymerisation of $L, D$-LA using complex $(\mathbf{1})^{(\mathrm{a})}$.

\begin{tabular}{|c|c|c|c|c|c|c|c|}
\hline Entry & {$[L, D$-LA $] /[\mathrm{Ti}]$ Ratio } & Conversion $^{(\mathrm{b})}(\%)$ & Activity $^{(\mathrm{c})}$ & $M w^{(\mathrm{d})}\left(\mathrm{g} \cdot \mathrm{mol}^{-1}\right)$ & $M_{n}^{(\mathrm{e})}\left(\mathrm{g} \cdot \mathrm{mol}^{-1}\right)$ & $\mathrm{MWD}^{(\mathrm{f})}$ & $T_{g}{ }^{(g)}$ \\
\hline 1 & 200 & $96 \%$ & 9.2 & 18400 & 15000 & 1.2 & 53.0 \\
\hline 2 & 500 & $87 \%$ & 21.0 & 19100 & 14900 & 1.3 & 52.1 \\
\hline 3 & 1000 & $88 \%$ & 42.3 & 27600 & 22400 & 1.2 & 50.0 \\
\hline 4 & 1994 & $67 \%$ & 65.3 & 43200 & 36900 & 1.2 & 41.7 \\
\hline
\end{tabular}

(a) $\mathrm{T}=130^{\circ} \mathrm{C}$, time $=3 \mathrm{~h} ;{ }^{(\mathrm{b})}$ determined by ${ }^{1} \mathrm{H} \mathrm{NMR} ;{ }^{(\mathrm{c})} \mathrm{kg}(\mathrm{PLDA}) \cdot \mathrm{mol}(\mathrm{Ti})^{-1} \cdot \mathrm{h}^{-1} ;{ }^{(\mathrm{d})}$ number average molar mass measured by HPLC-SEC; ${ }^{(\mathrm{e})}$ weight average molar mass measured by HPLC-SEC; ${ }^{(\mathrm{f})}$ molecular weight distribution; ${ }^{(\mathrm{g})}$ glass transition temperature as measured by DSC analysis.

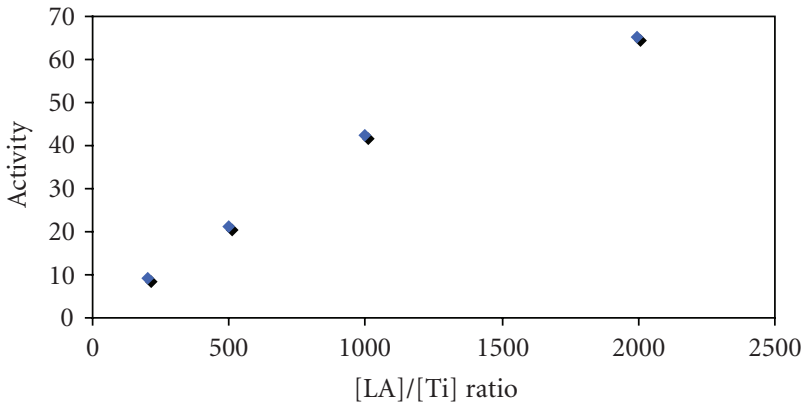

FIgURE 1: Variation of the activity as a function of the monomer/ catalyst ratio.

Size exclusion chromatography analysis of the polymers formed revealed that, as expected, the molecular weight $\left(M_{w}\right)$ increased with increasing $[L, D$-LA $] /[$ Ti $]$ ratio (Figure 2), the highest $M_{w}$ determined value being $43 \times$ $10^{3} \mathrm{~g} \cdot \mathrm{mol}^{-1}$ (Table 1 , entry 4). However, the $M_{w}$ values were much lower than expected. As already suggested for PLLA, this may be rationalized in terms of intramolecular transesterification during the propagation process $[21,28]$. The occurence of this phenomenon was confirmed by the presence in the MALDI-TOF spectra of peaks separated by intervals corresponding to half of the molecular weight of the monomer. Despite the observed transesterification process, the polymers obtained displayed molar mass distribution (MWD) indexes in the restricted range of 1.2-1.3, which indicates that the polymerisation process was relatively well controlled.

The DSC thermograms of the PLDA revealed only one glass transition temperature $\left(T_{g}\right)$ for each sample. This temperature decreased from 53.0 to $41.7^{\circ} \mathrm{C}$ when the size of

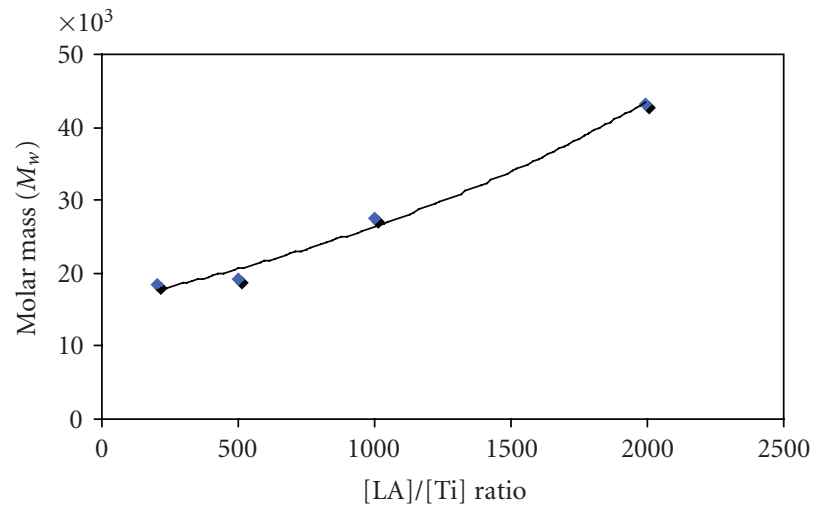

FIgURE 2: Variation of the molecular weight $\left(M_{w}\right)$ of PLDA as a function of the monomer/catalyst ratio.

the polymer chain increased $\left(M_{w}\right.$ increased) (Table 1, entries 1 to 4$)$.

Furthermore, the ${ }^{1} \mathrm{H}-\mathrm{NMR}$ spectrum of each sample revealed an unexpected microstructure (see an example in Figure 3). The spectrum shows two well-resolved peaks, of equal normalized intensity, at ca. 5.21 and $5.22 \mathrm{ppm}$ representing hexad stereosequences of isisi and iiisi, respectively. According to pairwise Bernoullian statistics, an equal probability for isisi and iiisi stereosequences implies that the polymerisation process is random [38-41]. Considering that the calixarene complex becomes chiral after insertion of the first incoming lactide (be it $L$ or $D$ ), it may be anticipated that for the following step a preferential insertion of one of the monomers ( $L$-LA or $D$-LA) takes place. In fact, careful analysis of the ${ }^{1} \mathrm{H}$ NMR spectrum revealed a higher intensity for the iii sequence (almost 4 times than each other peak). In keeping with the studies of Coates et al. [15, 
TABLE 2: Microwave- assisted polymerisation of $L, D$-LA using complex $(\mathbf{1})^{(\mathrm{a})}$.

\begin{tabular}{lcccccc}
\hline Entry & Time $(\mathrm{min})$ & Conversion $^{(\mathrm{b})}(\%)$ & Activity $^{(\mathrm{c})}$ & $\mathrm{Mw}^{(\mathrm{d})}\left(\mathrm{g} \cdot \mathrm{mol}^{-1}\right)$ & $M_{n}{ }^{(\mathrm{e})}\left(\mathrm{g} \cdot \mathrm{mol}^{-1}\right)$ & $\mathrm{MWD}^{(\mathrm{f})}$ \\
\hline 1 & 20 & $3 \%$ & 2.9 & - & - & - \\
2 & 40 & $38 \%$ & 17.1 & - & - \\
3 & 60 & $68 \%$ & 19.4 & 22300 & 17400 & - \\
4 & 80 & $88 \%$ & 18.9 & 27100 & 20900 \\
4 & &
\end{tabular}

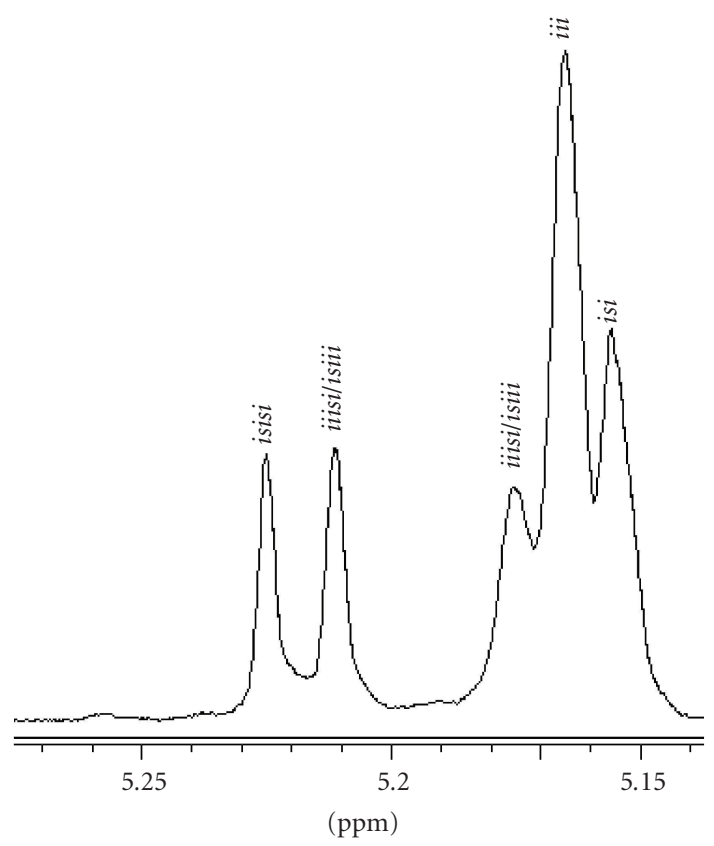

Figure 3: Homonuclear decoupled ${ }^{1} \mathrm{H}$ NMR spectrum of the methine region of PLDA obtained in Table 1, entry 1.

16], this observation may be assigned to a partial isotacticstereoblock structure. The relatively high proportion of isisi sequences may be interpreted in terms of a concomitant transesterification process. It is important to note that whatever the $[L, D$-LA $] /[\mathrm{Ti}]$ ratio applied, the polymerisation experiments led to PLDAs with similar microstructures, as revealed by the corresponding ${ }^{1} \mathrm{H}$ NMR spectra. These observations suggest that the stereochemistry of the insertion step is mainly controlled by a chain-end mechanism.

As a next step, the polymerisation reactions were carried out using microwave irradiation $(\mathrm{MW})$. For these runs, summarized in Table 2, a $[L, D$-LA $] /[\mathrm{Ti}]$ ratio of 200 was used. As expected, the conversion increased with increasing reaction time, the conversion reaching $88 \%$ after 80 minutes (Table 2, entry 4). The maximum activity was obtained after 60 minutes (Table 2, entry 3), longer polymerisation time leading to some polymer decomposition (a brown colour and smell of aldehyde could be noticed). Careful analysis of the conversion versus time diagram (Figure 4) revealed that the polymerisation requires an activation time of about 20 minutes. Interestingly, we observed that in these

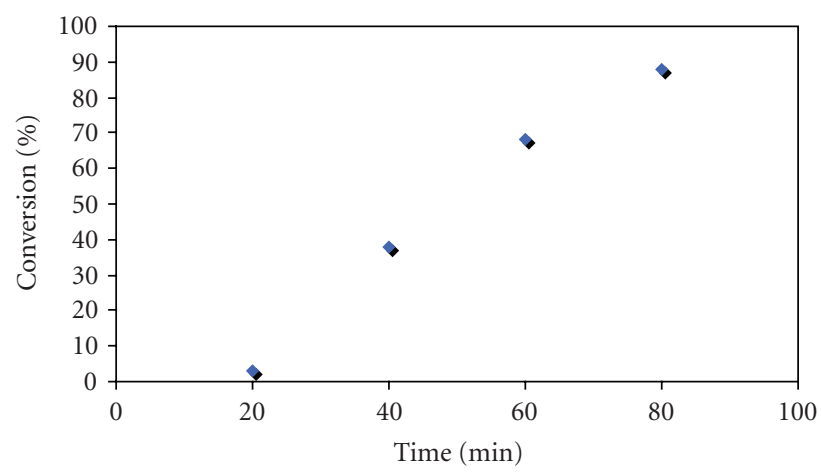

FIgURE 4: Conversion for $L, D$-LA against polymerisation time.

polymerisation reactions carried out under MW conditions, lower $M_{w}$ and $M_{n}$ values were obtained than those obtained using the standard heating technique.

\section{Conclusions}

In conclusion, we have presented for the first time the use of a calixarene complex in the ring-opening polymerisation of $L, D$-LA using thermal or microwave heating. By comparison with experiments carried out with conventional thermal heating, the use of microwaves energy induced an increase of the polymerisation rate, the thermal method leading to a slightly better control of the molecular weight and molecular weight distribution. The most striking feature of the polymers formed is their partial isotactic-stereobloc microstructure, which is likely controlled by a chain end mechanism. Further studies are in progress which will concentrate on modified versions of the titanium complex with the aim of improving the activity as well as the stereochemical control of the polymerisation reaction.

\section{Acknowledgments}

The authors are grateful to the University of Florence, the Italian MIUR (PRIN 2008 project. 200898KCKYInorganic nanohybrids based on bio-polyesters from renewable resources"), Regione Toscana ("Competitività regionale e occupazione” 2007-2013_project TeCon@BC, POR-FESR 2007-2013), and Ente Cassa di Risparmio di Firenze for the financial support. 


\section{References}

[1] J. Wu, T.-L. Yu, C.-T. Chen, and C.-C. Lin, "Recent developments in main group metal complexes catalyzed/initiated polymerization of lactides and related cyclic esters," Coordination Chemistry Reviews, vol. 250, no. 5-6, pp. 602-626, 2006.

[2] D. Garlotta, "A literature review of poly(lactic acid)," Journal of Polymers and the Environment, vol. 9, no. 2, pp. 63-84, 2001.

[3] B. J. O'Keefe, M. A. Hillmyer, and W. B. Tolman, "Polymerization of lactide and related cyclic esters by discrete metal complexes," Journal of the Chemical Society, Dalton Transactions, no. 15, pp. 2215-2224, 2001.

[4] O. Dechy-Cabaret, B. Martin-Vaca, and D. Bourissou, "Controlled ring-opening polymerization of lactide and glycolide," Chemical Reviews, vol. 104, no. 12, pp. 6147-6176, 2004.

[5] G. W. Coates, "Precise control of polyolefin stereochemistry using single-site metal catalysts," Chemical Reviews, vol. 100, no. 4, pp. 1223-1252, 2000.

[6] H. G. Alt and A. Köppl, "Effect of the nature of metallocene complexes of group IV metals on their performance in catalytic ethylene and propylene polymerization," Chemical Reviews, vol. 100, no. 4, pp. 1205-1222, 2000.

[7] O. Coulembier, M. K. Kiesewetter, A. Mason, P. Dubois, J. L. Hedrick, and R. M. Waymouth, "A distinctive organocatalytic approach to complex macromolecular architectures," Angewandte Chemie: International Edition, vol. 46, no. 25, pp. 4719-4721, 2007.

[8] M. Frediani, L. Rosi, M. Camaiti, et al., "Polylactide/perfluoropolyether block copolymers: potential candidates for protective and surface modifiers," Macromolecular Chemistry and Physics. In press.

[9] A. Kowalski, J. Libiszowski, T. Biela, M. Cypryk, A. Duda, and S. Penczek, "Kinetics and mechanism of cyclic esters polymerization initiated with tin(II) octoate. Polymerization of $\varepsilon$-caprolactone and L,L-Lactide co-initiated with primary amines," Macromolecules, vol. 38, no. 20, pp. 8170-8176, 2005.

[10] A. Kowalski, J. Libiszowski, A. Duda, and S. Penczek, "Polymerization of 1, 1-dilactide initiated by tin(ii) butoxide," Macromolecules, vol. 33, no. 6, pp. 1964-1971, 2000.

[11] A. Duda and S. Penczek, "In thermodynamics, kinetics, and mechanism of cyclic esters polymerization," in Polymers from Renewable Resources: Biopolyesters and Biocatalysis, C. Scholz and R. A. Gross, Eds., vol. 764 of ACS Symposium Series, pp. 160-198, Oxford University Press, Washington, DC, USA, 2000.

[12] O. Coulembier, P. Degée, J. L. Hedrick, and P. Dubois, "From controlled ring-opening polymerization to biodegradable aliphatic polyester: especially poly $(\beta$-malic acid $)$ derivatives," Progress in Polymer Science, vol. 31, no. 8, pp. 723-747, 2006.

[13] A. P. Dove, R. C. Pratt, B. G. G. Lohmeijer, et al., "Nheterocyclic carbenes: effective organic catalysts for living polymerization," Polymer, vol. 47, no. 11, pp. 4018-4025, 2006.

[14] E. Bukhaltsev, L. Frish, Y. Cohen, and A. Vigalok, "Single-site catalysis by bimetallic zinc calixarene inclusion complexes," Organic Letters, vol. 7, no. 23, pp. 5123-5126, 2005.

[15] T. M. Ovitt and G. W. Coates, "Stereochemistry of lactide polymerization with chiral catalysts: new opportunities for stereocontrol using polymer exchange mechanisms," Journal of the American Chemical Society, vol. 124, no. 7, pp. 1316-1326, 2002.

[16] B. M. Chamberlain, M. Cheng, D. R. Moore, T. M. Ovitt, E. B. Lobkovsky, and G. W. Coates, "Polymerization of lactide with zinc and magnesium $\beta$-diiminate complexes: stereocontrol and mechanism," Journal of the American Chemical Society, vol. 123, no. 14, pp. 3229-3238, 2001.

[17] J. Lee, Y. Kim, and Y. Do, "Novel chlorotitanium complexes containing chiral tridentate Schiff base ligands for ringopening polymerization of lactide," Inorganic Chemistry, vol. 46, no. 19, pp. 7701-7703, 2007.

[18] P. S. Umare, G. L. Tembe, K. V. Rao, U. S. Satpathy, and B. Trivedi, "Catalytic ring-opening polymerization of l-lactide by titanium biphenoxy-alkoxide initiators," Journal of Molecular Catalysis A, vol. 268, no. 1-2, pp. 235-243, 2007.

[19] J. Ejfler, M. Kobylka, L. B. Jerzykiewicz, and P. Sobota, “Titanium complexes supported by bis(aryloxo) ligand: structure and lactide polymerization activities," Journal of Molecular Catalysis A, vol. 257, no. 1-2, pp. 105-111, 2006.

[20] Y. Takashima, Y. Nakayama, K. Watanabe, et al., "Polymerizations of cyclic esters catalyzed by titanium complexes having chalcogen-bridged chelating diaryloxo ligands," Macromolecules, vol. 35, no. 20, pp. 7538-7544, 2002.

[21] M. Frediani, D. Sémeril, A. Mariotti, et al., "Ring opening polymerization of lactide under solvent-free conditions catalyzed by a chlorotitanium calix[4]arene complex," Macromolecular Rapid Communications, vol. 29, no. 18, pp. 15541560, 2008.

[22] M. Janke, Y. Rudzevich, O. Molokanova, et al., "Mechanically interlocked calix [4] arene dimers display reversible bond breakage under force," Nature Nanotechnology, vol. 4, no. 4, pp. 225-229, 2009.

[23] S. Safi, Z. Asfari, L. Ehret-Sabatier, M. Leroy, and A. Hagège, "Synthesis and characterization of immunogens based om calix[4] arene-crown- 6 for the generation of antibodies directed towards cesium ions," Bioconjugate Chemistry, vol. 17, no. 5, pp. 1346-1350, 2006.

[24] A. E. Motornaya, L. M. Alimbarova, E. A. Shokova, and V. V. Kovalev, "Synthesis and antiherpetic activity of N-(3-amino1-adamantyl)calix[4] arenes," Pharmaceutical Chemistry Journal, vol. 40, no. 2, pp. 68-72, 2006.

[25] A. Casnati, M. Fabbi, N. Pelizzi, et al., "Synthesis, antimicrobial activity and binding properties of calix[4] arene based vancomycin mimics," Bioorganic and Medicinal Chemistry Letters, vol. 6, no. 22, pp. 2699-2704, 1996.

[26] C. O. Kappe, D. Dallinger, and S. S. Murphee, in Practical Microwave Synthesis for Organic Chemists, Wiley-VCH, Weinheim, Germany, 2008.

[27] A. Loupy, Microwaves in Organic Synthesis, Wiley-VCH, Weinheim, Germany, 2006.

[28] M. Frediani, D. Sémeril, D. Matt, et al., " $L$-Lactide polymerization by calix[4]arene-titanium (IV) complex using conventional heating and microwave irradiation," E-Polymers, no. 019 , pp. 1-8, 2010.

[29] R. Hoogenboom and U. S. Schubert, "Microwave-assisted polymer synthesis: recent developments in a rapidly expanding field of research," Macromolecular Rapid Communications, vol. 28, no. 4, pp. 368-386, 2007.

[30] F. Wiesbrock, R. Hoogenboom, and U. S. Schubert, "Microwave-assisted polymer synthesis: state-of-the-art and future perspectives," Macromolecular Rapid Communications, vol. 25, no. 20, pp. 1739-1764, 2004.

[31] C. Zhang, L. Liao, and S. Gong, "Microwave-assisted synthesis of PLLA-PEG-PLLA triblock copolymers," Macromolecular Rapid Communications, vol. 28, no. 4, pp. 422-427, 2007.

[32] H. Li, L. Liao, and L. Liu, "Kinetic investigation into the nonthermal microwave effect on the ring-opening polymerization of E-caprolactone," Macromolecular Rapid Communications, vol. 28, no. 4, pp. 411-416, 2007. 
[33] Y. M. Zhang, P. Wang, N. Han, and H. F. Lei, "Microwave irradiation: a novel method for rapid synthesis of D,L-lactide," Macromolecular Rapid Communications, vol. 28, no. 4, pp. 417-421, 2007.

[34] S. Jing, W. Peng, Z. Tong, and Z. Baoxiu, "Microwaveirradiated ring-opening polymerization of D,L-lactide under atmosphere," Journal of Applied Polymer Science, vol. 100, no. 3, pp. 2244-2247, 2006.

[35] C. Zhang, L. Liao, and L. Liu, "Rapid ring-opening polymerization of D,L-lactide by microwaves," Macromolecular Rapid Communications, vol. 25, no. 15, pp. 1402-1405, 2004.

[36] M. Frediani, D. Sémeril, A. Comucci, et al., "Ultrahighmolecular-weight polyethylene by using a titanium calix[4]arene complex with high thermal stability under polymerization conditions," Macromolecular Chemistry and Physics, vol. 208, no. 9, pp. 938-945, 2007.

[37] U. Just, S. Weidner, P. Kilz, and T. Hofe, "Polymer reference materials: round-robin tests for the determination of molar masses," International Journal of Polymer Analysis and Characterization, vol. 10, no. 3-4, pp. 225-243, 2005.

[38] K. A. M. Thakur, R. T. Kean, E. S. Hall, M. A. Doscotch, and E. J. Munson, "A quantitative method for determination of lactide composition in poly(lactide) using $1 \mathrm{H}$ NMR," Analytical Chemistry, vol. 69, no. 21, pp. 4303-4309, 1997.

[39] M. T. Zell, B. E. Padden, A. J. Paterick, et al., "Direct observation of stereodefect sites in semicrystalline poly(lactide) using 13C solid-state NMR," Journal of the American Chemical Society, vol. 120, no. 48, pp. 12672-12673, 1998.

[40] K. A. M. Thakur, R. T. Kean, E. S. Hall, et al., "Highresolution $13 \mathrm{C}$ and $1 \mathrm{H}$ solution NMR study of poly(lactide)," Macromolecules, vol. 30, no. 8, pp. 2422-2428, 1997.

[41] J. L. Espartero, I. Rashkov, S. M. Li, N. Manolova, and M. Vert, "NMR analysis of low molecular weight poly(lactic acid)s," Macromolecules, vol. 29, no. 10, pp. 3535-3539, 1996.

[42] G. Montaudo and R. P. Lattimer, Mass Spectrometry of Polymers, CRC Press, Boca Raton, FL, USA, 2002.

[43] G. Montaudo, M. S. Montaudo, C. Puglisi, et al., "Evidence for ester-exchange reactions and cyclic oligomer formation in the ring-opening polymerization of lactide with aluminum complex initiators," Macromolecules, vol. 29, no. 20, pp. 6461$6465,1996$.

[44] A. P. Mathew, K. Oksman, and M. Sain, "The effect of morphology and chemical characteristics of cellulose reinforcements on the crystallinity of polylactic acid," Journal of Applied Polymer Science, vol. 101, no. 1, pp. 300-310, 2006. 

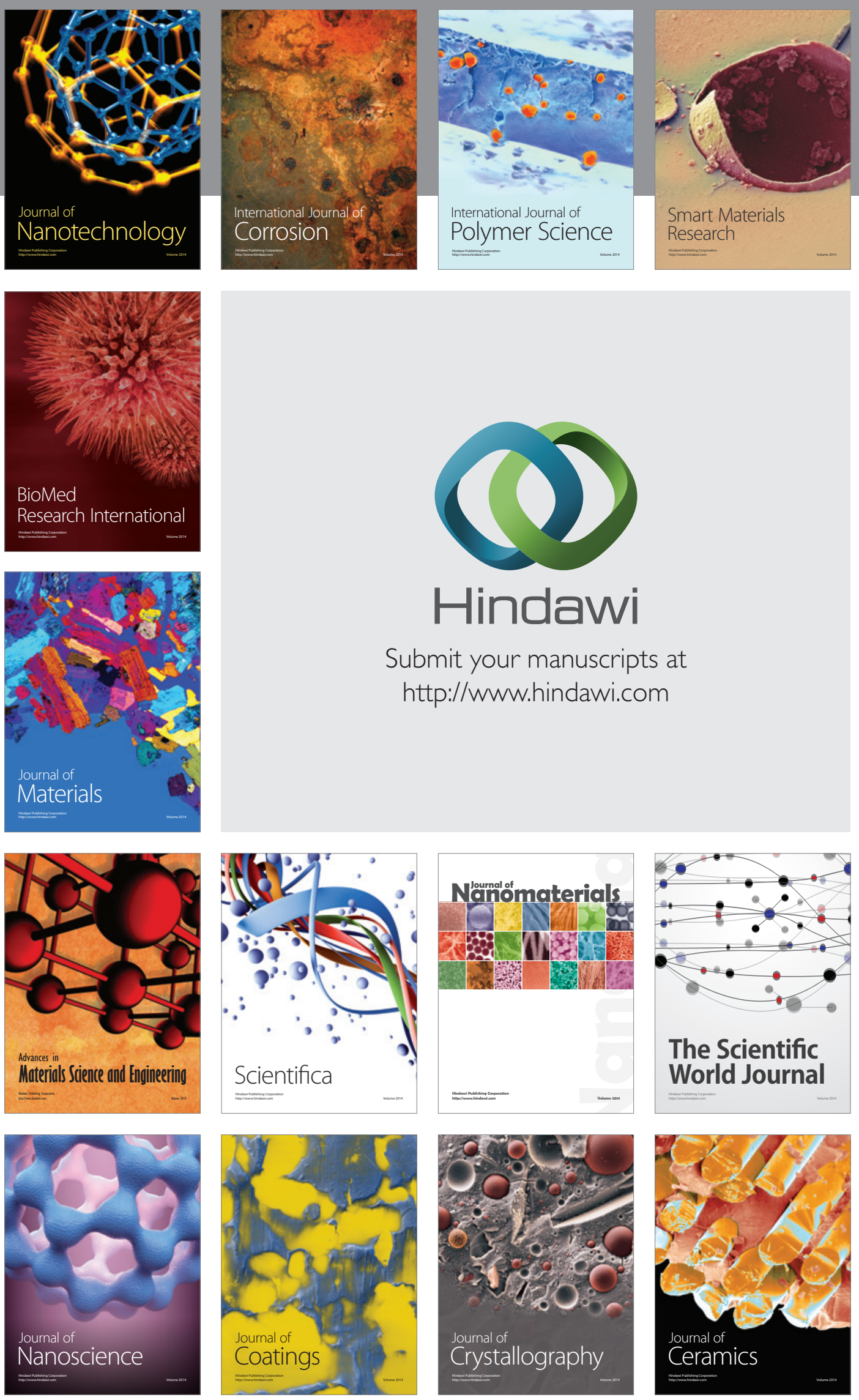

The Scientific World Journal

Submit your manuscripts at

http://www.hindawi.com

\section{World Journal}

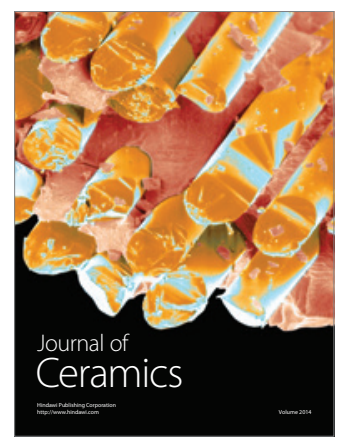

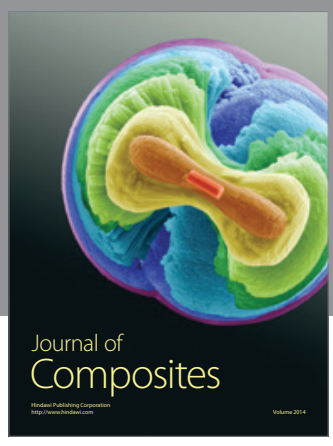
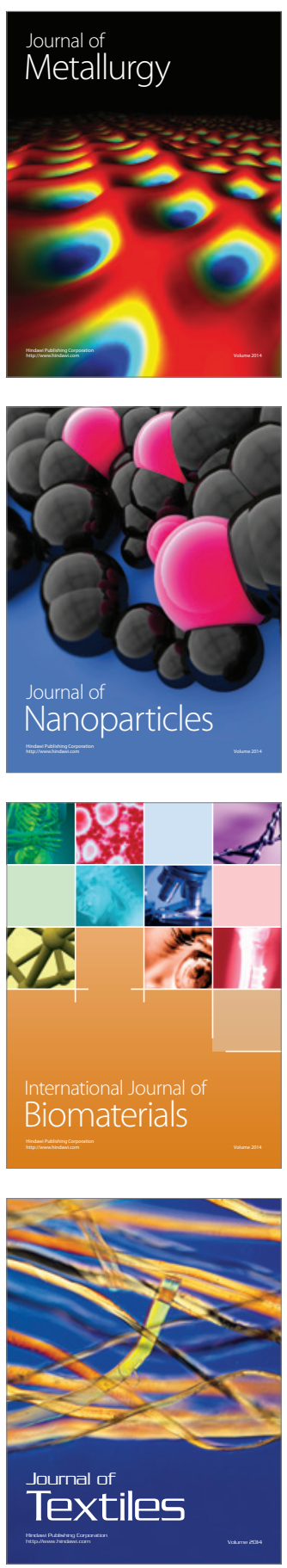